\title{
A COMPARISON OF THE SHEEP CELL AND LATEX AGGLUTINATION TESTS IN RHEUMATOID ARTHRITIS
}

\author{
BY \\ V. L. STEINBERG, P. D. ROBERTS, AND S. P. LOCK \\ From the Department of Physical Medicine and the Clinical Laboratories, the London Hospital
}

(RECEIVED FOR PUBLICATION MAY 7, 1959)

The serum of patients with rheumatoid arthritis contains a factor which causes agglutination of sensitized particulate bodies. This phenomenon has been demonstrated using sheep red cells (Waaler, 1940), collodion particles (Wallis, 1946), bacteria (Wager, 1950), polysterene latex particles (Singer and Plotz, 1956), and bentonite (Bozicevich, Bunim, Freund, and Ward, 1958). Rose, Ragan, Pearce, and Lipman (1948) devised a diagnostic test using sensitized sheep red cells, since when a considerable literature has appeared describing modifications of this test, its clinical significance, and the mechanisms involved (Ziff, 1957 ; Kellgren and Ball, 1959).

Because of its relative simplicity the latex test has recently attracted more attention and a number of modifications have been described, including the use of a glycine buffer in the place of the original borate buffer (Egghart, Wiedermann, and Braunsteiner, 1957 ; Valkenburg and Mos, 1958), a drop dilution technique (Rothermich and Philips, 1957), and the use of the patient's own gamma globulin. (Singer and Plotz, 1958a). Bartfeld, Mahood, and Hartung (1958) and Burby and Behr (1958) have compared the results of sheep cell agglutination tests and the latex test. A slide agglutination test has recently been described (Singer and Plotz, 1958b).

The object of the present investigation was to compare the results of sheep cell agglutination tests and latex tests performed in parallel on sera from a large physical medicine department, with the possibility of adopting the much quicker and simpler latex test in place of the sheep cell test.

\section{Method}

Ball's (1950) modification of the sheep cell test was used. The test consists essentially of inactivating the complement in the test serum, absorbing the naturally occurring sheep cell agglutinins, and finally adding sheep cells sensitized with rabbit anti-sheep serum to serial dilutions of the $i r$ decomplemented absorbed serum. After incubation at $37^{\circ} \mathrm{C}$. for one hour and refrigeration at $4^{\circ} \mathrm{C}$. $\infty$ overnight, the tubes are read for agglutination of the 은 sensitized sheep cells by the "rheumatoid factor." A titre of 1 in 16 or over was interpreted as a $c$ positive test.

The latex agglutination tests were performed essentially as originally described by Singer and Plotz (1956). Polyvinyl toluene latex particles (Dow Chemical Company, Michigan, U.S.A.) of particle size $0.81 \mu$ were mixed with human gammळ $\vec{\oplus}$ globulin and added to serial dilutions of the teef serum from 1 in 20 to 1 in 10,240. After incubatio for two hours at $56^{\circ} \mathrm{C}$. the tubes were read for agglutination of the particles and a titre of 1 in 20 or over interpreted as a positive test. It was found that after two hours' incubation the tests could be read easily with the aid of a small-aperture $\mathscr{Q}$ transmitted light. Centrifugation and refrigeration $\overrightarrow{\vec{P}}$ before reading, as described by Singer and Plotz $\frac{3}{3}$ (1956), was unnecessary. In a positive test a prozone was frequently noted, with only slight agglutination in the first tube, increasing through the second tube to reach maximal agglutination in the third tube, the agglutination then progressively diminishing to the end-point.

\section{Results}

Five hundred and four sheep cell and latex agglutination tests were performed in parallel. The results of the test have been arranged in four groups as follows:

Group I $\quad . . \quad \ldots$ Both tests positive in 157 cases

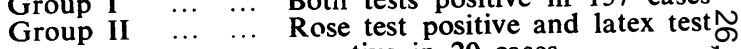
Group III _.. $\quad \ldots \quad \begin{aligned} & \text { negative in } 20 \text { cases } \\ & \text { Rose test negative and latex test } \tilde{O}\end{aligned}$ Group IV $\ldots \quad \ldots \quad \begin{aligned} & \text { positive in } 16 \text { cases } \\ & \text { Both tests negative in } 311 \text { cases }{ }^{\mathrm{C}}\end{aligned}$ The two tests corresponded in 468 or $93 \%$ of tests.

All the patients with rheumatoid arthritis weres? again classified according to the American Rheumatism Association criteria (Ropes, Bennett, Cobb, Jacox, and Jessar, 1956). 
The 157 cases in Group I were classified as rheumatoid arthritis in 151 , probable rheumatoid arthritis in one, possible rheumatoid arthritis in two, rheumatoid arthritis with psoriasis in two, and collagen disease in one. The patient with probable rheumatoid arthritis subsequently developed sufficient criteria to make the diagnosis "definite." The two cases of rheumatoid arthritis with psoriasis were typical rheumatoid with psoriasis and not cases of psoriatic arthritis ; in the final analysis of the rheumatoid material these two cases are therefore included. In spite of a necropsy a final diagnosis was not reached in the case labelled "collagen disease."

Comparison of the titres of the Rose tests and latex tests suggests a tendency for the mid to high Rose titres to be associated with high latex titres. It was not possible, however, to predict the titre of one by knowing the titre of the other. When positive, latex titres were never below 80 and usually higher (Table I).

TABLE I

COMPARISON OF 157 POSITIVE ROSE AND LATEX TESTS BY TITRE

\begin{tabular}{|c|c|c|c|c|c|c|c|c|c|}
\hline $\begin{array}{l}\text { Rose } \\
\text { Tests } \\
\text { Total }\end{array}$ & 4 & 9 & 13 & 19 & 25 & 30 & 21 & 36 & 157 \\
\hline $\begin{array}{r}2,048 \\
1,024 \\
512 \\
256 \\
128 \\
64 \\
32 \\
16\end{array}$ & $\begin{array}{l}- \\
= \\
\overline{-} \\
4\end{array}$ & $\begin{array}{l}\text { 二 } \\
\text { - } \\
3 \\
2 \\
3 \\
1\end{array}$ & $\begin{array}{l}\text { - } \\
- \\
1 \\
3 \\
3 \\
3 \\
3\end{array}$ & $\begin{array}{l}- \\
- \\
1 \\
4 \\
4 \\
5 \\
5\end{array}$ & $\begin{array}{l}1 \\
2 \\
3 \\
3 \\
5 \\
8 \\
3\end{array}$ & $\begin{array}{l}1 \\
3 \\
5 \\
4 \\
9 \\
3 \\
5\end{array}$ & $\begin{array}{l}1 \\
2 \\
2 \\
6 \\
2 \\
7 \\
1\end{array}$ & $\begin{array}{l}3 \\
3 \\
4 \\
9 \\
9 \\
4 \\
3 \\
1\end{array}$ & $\begin{array}{r}6 \\
3 \\
11 \\
21 \\
32 \\
29 \\
32 \\
23\end{array}$ \\
\hline $\begin{array}{l}\text { Latex } \\
\text { tests }\end{array}$ & 80 & 160 & 320 & 640 & 1,280 & 2,560 & 5,120 & 10,240 & 157 \\
\hline
\end{tabular}

Group II, with a positive Rose test and negative latex test, included 15 cases of rheumatoid arthritis, one of probable rheumatoid arthritis, one of psoriatic arthropathy, one of sacro-iliitis, and one definite and one probable case of disseminated lupus erythematosus. Nine of the patients with rheumatoid arthritis were " classical " cases and in the other six it was just possible to make a diagnosis of definite rheumatoid arthritis ; in two of these latter cases the Rose test was the fifth criterion, although further criteria subsequently developed. The patient with psoriatic arthropathy was typical, with terminal involvement of interphalangeal joints. Both patients with disseminated lupus were early cases without locomotor signs. The patient with sacroiliitis has had a persistently positive Rose test, no radiological evidence of spondylitis, and radiotherapy has been ineffective. The titres of the Rose test in this group were mostly low, with nine at 1 in 16 , eight at 1 in 32 , one at 1 in 64 , and two at 1 in 128. Both the patients with a titre of 1 in 128 had classical rheumatoid arthritis.

Group III, with a positive latex test and negative Rose test, included 10 cases of rheumatoid arthritis, one of probable rheumatoid arthritis, one of possible rheumatoid arthritis, one of arthritis with psoriasis, one of Reiter's disease, one of the shoulder-hand syndrome, and one case of uveitis. Eight of the 10 definite rheumatoid cases were classical, one had a history of six months and five criteria without the latex test, and one a short history of joint involvement and a previous history of suspected but unconfirmed discoid lupus. The case classified as probable rheumatoid arthritis presented with rupture of the extensor tendons of the hand due to attrition. The patient with possible rheumatoid arthritis gave a very short history, and all investigations other than the latex test were negative. The case of arthritis and psoriasis had a long history of psoriasis and a brief history of joint pain and swelling; he subsequently died with acute nephritis.

Group IV, with both tests negative, contained over 25 conditions but included 81 patients with a diagnosis of rheumatoid arthritis.

In all, sera from 259 rheumatoid patients were tested, both tests being positive in 153 , the Rose test positive and the latex negative in 15 , the Rose test negative and the latex positive in 10 , and both tests negative in 81 . There was therefore agreement in 234 rheumatoid sera out of a total of 259 , or in $90 \%$. Considering Groups II and III, the overall results were:

$\begin{array}{lllll}\text { Both tests positive } & \ldots & \ldots & 153(59 \%) \\ \text { Rose test positive } & \ldots & \ldots & 168(64.8 \%) \\ \text { Latex test positive } & \ldots & \ldots & 163(62.9 \%) \\ \text { Either test positive } & \ldots & \ldots & 178(68.7 \%)\end{array}$

\section{Discussion}

It is clear that the results of the sheep-cell and latex agglutination tests coincide in the majority of cases, with each test having approximately the same sensitivity. If both tests were performed together this would result in a slightly higher total of positive serology, but the slight advantage gained would be out of proportion to the work involved. The latex test is much quicker and simpler to perform, 20 or more tests being easily set up and read in a morning. One possible disadvantage of replacing the sheep cell test by the latex test may be that the titre of the sheep cell test has been related to the prognosis of the disease (Duthie, Brown, Knox, and Thompson, 1957): there seems to be no correlation between 
the titre of the sheep cell tests and latex tests in this series (Table I).

It would be useful to have a rapid screening test for the "rheumatoid factor" in serum. In devising such a test, either on a slide or in tubes, the prozone phenomenon noted in the latex test must be borne in mind.

\section{Summary}

Five hundred and four sheep cell and latex agglutination tests were performed in parallel and the two tests gave coincidental positive or negative results in $93 \%$. There was no correlation between the titres of positive tests. It is suggested that the latex test is a satisfactory simple alternative to the sheep cell test in routine diagnostic work.

We are grateful to Dr. R. M. Mason and Dr. W. S. Tegner for permission to investigate patients under their care and to Dr. J. Perrin for advice in this work.
Ball, J. (1950). Lancet, 2, 520.

REFERENCES

Bartfeld, H., Mahood, E., and Hartung, E. F. (1958). Ann. rheum. Dis., 17, 83.

Bozicevich, J., Bunim, J. J., Freund, J., and Ward, S. B. (1958). Proc. Soc. exp. Biol. (N.Y.), 97, 180.

Burby, G., and Behr, G. (1958). Lancet, 2, 1157.

Duthie, J. J. R., Brown, P. E., Knox, J. D. E., and Thompson, M. (1957). Ann. rheum. Dis., 16, 411.

Egghart, F., Wiedermann, G., and Braunsteiner, H. (1957). Wien. Z. inn. Med., 38, 364.

Kellgren, J. H., and Ball, J. (1959). Brit. med. J., 1, 523.

Ropes, M. W., Bennett, G. A., Cobb, S., Jacox, R., and Jessar, R. A. (1956). Bull. rheum. Dis., 7, 121.

Rose, H. M., Ragan, C., Pearce, E., and Lipman, M. O. (1948). Proc. Soc. exp. Biol. (N.Y.), 68, 1 .

Rothermich, N. O., and Philips, V. K. (1957). J. Amer. med. Ass., 164, 1999.

Singer, J. M., and Plotz, C. M. (1956). Amer. J. Med., $21,888$. (1958a). Arthr. and Rheum., 1, 142.

(1958b). J. Amer. med. Ass., 168, 180.

Valkenburg, H. A., and Mos, C. A. de (1958). Ann. rheum. Dis., 17, 338.

Waaler, E. (1940). Acta path. microbiol. scand., 17, 172.

Wager, O. A. (1950). Ann. Med. exp. Fenn., 28, 154.

Wallis, A. D. (1946). Amer. J. med. Sci., 212, 716.

Ziff, M. (1957). J. chron. Dis., 5, 644. 